\title{
Beyond Training: Supporting Teachers of Deaf Students with Additional Disabilities in the Classroom: A Qualitative Case Study
}

\author{
Millicent M. Musyoka ${ }^{1, *} \&$ Mary A. Gentry ${ }^{1}$ \\ ${ }^{1}$ Deaf Studies/Deaf Education Department, Lamar University, Beaumont, Texas, United States \\ *Correspondence: Lamar University, Deaf Studies/Deaf Education Department, PO Box 10113, Beaumont, TX \\ 77710, United States. E-mail: mmusyoka@lamar.edu
}

Received: April 5, 2020

Accepted: April 24, 2020 Online Published: May 16, 2020

doi:10.5430/jct.v9n2p33

URL: https://doi.org/10.5430/jct.v9n2p33

\begin{abstract}
This study investigated teachers' perceptions of the nature of support, or lack thereof, while teaching deaf students with additional disabilities (DSAD). A total of forty teachers, from five schools in four states in the United States, participated in the study. A content analysis of written responses to four open-ended questions, using a questionnaire survey was conducted. As a result, six themes emerged from the study, including (i) resources, (ii) managerial support, (iii) personnel staff services, (iv) team support, (v) mentoring, and (vi) professional development. Implications of the findings related to school administrators and preparation programs for educational leadership were discussed.
\end{abstract}

Keywords: deaf, teachers, teacher's support, additional disabilities

\section{Introduction}

The learning process in schools is influenced by several factors, in which the teacher is of key importance. In the United States, classrooms serving students with students with disabilities, teachers' responsibilities are aligned with the Individual with Disability Education Act (IDEA) 2004 (Apling \& Jones, 2004). IDEA ensures that all students with disabilities have access to quality education, just as their counterpoints. Also, their academic achievement is expected to be measured with the district and statewide assessment programs used for all students, or an alternate assessment used for students who are unable to participate in the general assessment (Katsafanas, 2006). To do so, the first responsibility for teachers is to set realistic behavioral and academic expectations (Alderman, 2004; Stronge, 2002; Tsiplakides \& Keramida, 2010).

According to Stronge (2002), teachers not only have to set expectations for student achievement but also support students to become responsible and accountable in meeting specific expectations. Another responsibility of teachers is to attend to the individual students' differences, by adopting adaptive learning patterns and providing appropriate instructional strategies, and assessment including individualized instruction (Alderman, 2004; Gersten, Keating, Yovanoff, \& Harniss, 2001; McGrew, Johnson, Cosio, \& Evans, 2004; Zigmond \& Baker, 1995). Also, teacher's responsibilities include developing Individualized Educational Plans (IEPs), and collaborating with parents and other professionals to adequately attend to the needs of the students (Wasbaurn-Moses, 2005; York-Barr, Sommerness, Duke, \& Ghere, 2005).

Albrecht, Johns, Mounsteven, \& Olorunda, (2009) reported that teachers' attrition was as a result of lack of support for instance (a) lack of administration understanding of the program, (b) administrators' attitude, (c) lack of needed resource material and services, (d) inadequate teachers' time, and (e) conflicts with discipline-related issues. Similarly, Griffin et al., 2009, reported that teachers experienced lack of support from administrators in attending to their responsibilities, such as, working with students with more than one disability, teaching multiple content areas classrooms, lack of access to resources, attending to behavior management issues, and overwhelming paperwork from administrators. Other research noted that teachers prefer mentors to be match based on the needs and in particular mentors who understood their students' type of disability and grade level (Darling-Hammond, 2003; Dempsey, Arthur-Kelly, \& Carty, 2009; Graves, 2010; Smith \& Ingersoll, 2004; Whitaker, 2000; White \& Mason, 2006). Using technology to connect teachers to matching mentors may provide support to teachers in areas without appropriate mentor. (Dempsey et al., 2009; Israel, Carnahan, Snyder, \& Williamson, 2013). 
Previous research shows the nature of teachers' need for support varied with the teachers' years of teaching experience and the type of students' disabilities (Cancio, Albrecht, \& Johns, 2013; Otto \& Arnold, 2005). Otto and Arnold (2005) study findings showed that $69 \%$ of the 228 special education teachers reported that they had administrator support, but did not report the specific type of support. Otto and Arnold (2005) argued that the possible reason why teachers who had less than five years reported experiencing less support, compared to those who had five years or more, was because beginning special education teachers tend to be overwhelmed by the responsibilities of the job. Thus, Otto and Arnold (2005) suggest it is possible for the beginner teachers to report lack of support from administrators as an "excuse" for stress-related complaints.

Similarly, Cancio, Albrecht \& Johns (2013), found that teachers, who reported less need for support, were those who had been on the job longer and planned to stay in the field. Cancio et al. (2013) categorized teachers' support as emotional support; instruments support, informational support, and appraisal support. Emotional support referred to showing teachers respect, trust, and worthiness, including interest in their work and maintaining open communication. Instrumental support focused on providing teaching resources, adequate space and ensuring adequate time for teaching and nonteaching duties. Informational support was related to providing teachers with information to improve classroom practices through professional development. Appraisal support involved providing ongoing personnel appraisals, such as frequent and constructive feedback about their performance, information about what constitutes effective teaching, and clear guidelines regarding job responsibilities. Their results showed most teachers needed both, emotional support and informational support. The need for emotional support and informational support is reported in other research (Billingsley \& Cross, 1992; Cross \& Billingsley, 1994; Ingersoll, 2001; Martin, 2008; Richard, 2007, 2004). In particular, Richard $(2007,2004)$ found that the greatest need for teachers with six to ten years of experience, and those with more than ten years of experience, is to be respected as professionals for their knowledge and experience. Emotional support for seasoned teachers involved the principal asking their opinion, valuing their input, and giving them opportunities for decision-making, while providing mentoring and informational support to new teachers (Richard, 2007, 2004). The goal of this study was to examine if teachers of Deaf Students with Additional Disabilities (DSAD) reported similar support systems in their institutions.

A literature review on the nature of support offered to teachers of Deaf Students with Additional Disabilities (DSAD), showed a lack of research. Previous studies regarding teaching DSAD have focused on the teachers and the skills they must have (Bruce, DiNatale, \& Ford, 2008; Luckner \& Carter, 2001; Musyoka, Gentry, \& Meek, 2017). Several studies have reported teachers' lack of skills to teach DSAD (Dodd and Scheetz, 2003; Guardino, 2015; Musyoka, Gentry, Bartlett, 2016; Musyoka, Gentry, \& Meek, 2017). Additionally, teachers of students with various disabilities, tend to experience role conflict, role ambiguity, feelings of being pressured and unrealistic expectations (Musyoka, Gentry \& Bartlett, 2015; Skaalvik \& Skaalvik, 2007). Most studies have recommended providing teachers of DSAD professional development as they continue to work with these students (Bruce, DiNatale \& Ford, 2008; Dodd \& Scheetz, 2003; Guardino, 2015; Luckner \& Carter, 2001; Musyoka, Gentry, \& Bartlett, 2016; Musyoka, Gentry, \& Meek, 2017). Additionally, a recommendation has been made to teacher preparation programs to examine how their programs can provide graduating teachers with knowledge and skills in attending the needs of DSAD (Jones and Ewing, 2002; Musyoka, Gentry, Bartlett, 2016; Musyoka, Gentry \& Meek, 2017). Although providing teachers with knowledge and skills is essential in teaching this population, one factor that can impact a teachers' efficacy is the support available to them (Prather-Jones, 2011). It is essential for those teachers who are in the classrooms before professional development occurs, to identify the nature of support they need (Billingsley \& Cross, 1992; Cancio, Albrecht \& Johns, 2013; Cross \& Billingsley, 1994; Ingersoll, 2001; Martin, 2008; Richard, 2007, 2004). Consequently, the purpose of the current study was to examine teachers' perceptions of the nature of support, or lack there of, while teaching DSAD in selected program across the United States.

\section{Methods}

The current study adopted a qualitative study design to understand the perceptions of teachers of DSAD in four selected program in the United Stated related to the support they received. Qualitative research methods are used to investigate people's lived experiences and interpret the meanings of those experiences (Bogdan \& Biklen, 2003; Creswell, 2005; Denzin \& Lincoln, 2000). According to Creswell (2005), qualitative research methods provide in-depth descriptions and rich contextual pictures that provide a deeper understanding of how participants perceive a phenomenon. The phenomenon in the current was the type of support needed or provided by their schools. To examine the selected case, the qualitative research questions begin with how or what, so that the researcher can gain an in-depth understanding of case study (Patton, 2002). Thus, in this study, the guiding research question was the "What are 
teachers' perceptions of the support they need when teaching DSAD?" The case study allowed the researcher to make meaning out of real-life events of teachers of students who are DSAD.

\subsection{Sampling Procedures}

Purposive sampling was used to select the schools and participants involved in this study. This method of selecting participants enabled the researchers to select participants who could best provide information and responses that attended to the research questions (Creswell, 2013; Patton, 2015). According to Yin (2009) prior to collecting data, a defined set of operational criteria, whereby candidates will be deemed qualified to serve as cases, was set. The criterion used in selecting the participating teachers was related to their experience teaching a deaf student that had been assessed and identified as DSAD. Preliminary fieldwork to study the feasibility of doing the study enabled the researchers to locate schools willing to participate. During the feasibility study, we sent an email to schools with deaf students, both schools for the deaf and mainstream programs, and explained the focus of the research. Only five schools agreed to participate and responded to our request. After identifying the school, the school's principals and superintendents assisted in identifying the teachers who had DSAD in their classes.

\subsection{Participants}

Table 1. Participants Demographics

\begin{tabular}{|c|c|}
\hline \multicolumn{2}{|c|}{ Participants Demographics } \\
\hline Sex & Women: 26 \\
\hline & Men:14 \\
\hline \multirow[t]{5}{*}{ Type of certification*a } & No certification: 1 \\
\hline & Deaf education: 31 \\
\hline & Special education: 11 \\
\hline & General education: 12 \\
\hline & Other certification: 8 \\
\hline \multirow[t]{3}{*}{ Teaching experience* } & $1-5$ years: 8 \\
\hline & $6-10$ years: 11 \\
\hline & More than 10 years: 21 \\
\hline \multirow[t]{3}{*}{ Grade level taught } & EC-6: 11 \\
\hline & Middle school: 12 \\
\hline & High school \& other: 17 \\
\hline \multirow[t]{4}{*}{ Teacher prep program attended } & Deaf education: 14 \\
\hline & Special Education: 7 \\
\hline & General Education: 8 \\
\hline & Other programs: 11 \\
\hline \multicolumn{2}{|c|}{${ }^{a}$ some teachers hold more than one type of certification } \\
\hline \multicolumn{2}{|c|}{ b teacher's' overall years of teaching deaf students. } \\
\hline
\end{tabular}

This study involved 40 teachers from five schools in four states in the United States, including Louisiana, Texas, Mississippi, and Indiana. Four of the five schools were schools for the deaf while one was a mainstream school with self-contained classrooms for deaf students. Based on the criteria set for participation, the number of teachers who participated in the study ranged varied from one school to another. It is not possible to identify the number of teachers per school because it was an online survey, and we did not include in the questionnaire an item to identify the school. Some of the teachers taught DSAD in separate classrooms/program for DSAD within the deaf education school. Other teachers taught DSAD in integrated classrooms with DSAD and typical deaf students then used "Pull out Programs" to support them. Teachers in the mainstream, self-contained classroom, handled both deaf students with and without disabilities in their same class. The participating teachers included $35 \%$ male and $65 \%$ female 
respondents. The majority of the participants $(42.5 \%)$ were teachers in high school, and other areas, such as vocational classes. A total of 30\% were teachers in middle school, and $27.5 \%$ were teachers in grades EC-6. Most of the teachers were hearing.

The participants of the current study were teachers hence specific information on students' degree of hearing loss was not collected. The participating teachers identified their students as deaf and users of American Sign Language (ASL) as the communication mode. Additionally, teachers identified the most prevalent additional disabilities to include intellectual difference, autism, attention deficit hyperactive disorders (ADHD), specific learning disabilities, and deaf blindness. Participants demographics are summarized in Table 1.

\subsection{Research Questions}

This study investigated the support(s) provided to and identified as important to teach DSAD. The main research question was "What are teachers' perceptions of the support they need when teaching DSAD?"

\subsection{Data Collection Instrument}

The current study focuses only on four open-ended questions included in a teacher survey questionnaire which was a self-reported experiences of teachers of DSAD. The researchers independently developed the survey questionnaire. The questionnaire items were derived from the literature reviewed on deaf students with additional disabilities, discussions with students taking a course on teaching deaf students with multiple disabilities, student interns experiences related to college instructors and internship/practicum supervisors. The four open-ended questions in the teacher survey questionnaire included the following:

1. Briefly, explain how you made it this far as a teacher for DSAD.

2. How would you describe your current teaching experience?

3. What current challenges are you facing in teaching DSAD?

4. What type of assistance would you like to receive from your school?

A pretest of the survey questionnaire items was conducted with a group of students who were currently taking, or had completed, a course on multiple disabilities and deafness. To attend to the ethical issues of coercion related with dual teaching/research roles data was collected data after the class was over and students had their grade for the class (Comer, 2009; Ferguson, Yonge \& Myrick, 2006; Ridley, 2009). Also, students were fully informed and given the voluntarily chose whether or not to participate in the research and no incentive for participation was offered. Additionally, students were offered the option to withdraw from the study after giving consent by closing the browser window before clicking submit.

\subsection{Data Collection Procedures}

Survey Monkey, an online data collection tool, was used to disseminate the survey questionnaire. To receive informed consent from participants an information sheet was created as the first page of the online survey and participants were required to check a box to indicate consent before beginning the survey (Ferguson, Yonge, \& Myrick, 2004; Mahon, 2013) To assist with maintaining the anonymity of the participants the researcher deleted the IP addresses which are personally identifiable information before saving the data (Barchard \& Williams, 2008; Buchanan \& Hvidzak, 2009). The data was collected in Fall 2014 and Spring 2015.

The participants were not limited to space in providing their responses to these open-ended questions. There were no direct questions that focused on specific support, but more so of their description on how they made it thus far, their experiences and challenges in teaching DSAD, the type of assistance they needed and received. Two researchers were involved in data collection, data analysis and in writing the findings report. Both researchers are faculty in a deaf education teacher preparation program.

\subsection{Data Analysis}

Content- analysis was selected as an appropriate data analysis approach for the current study. Qualitative content analysis refers "to characterize the collection of generic qualitative analytical moves that are applied to establish patterns in the data" (Dörnyei, 2007, p. 254). The content analysis includes coding for themes, looking for patterns, and making interpretations. The content-based analysis in this study involved four significant steps: (a) transcriptions (b) data coding (b) categorization for themes and looking for patterns and (c) interpreting the data and ultimately drawing conclusions.

The researchers retrieved all the responses from the open-ended questions and developed a transcript. Next, the researchers read and reviewed the transcripts numerous times to identify patterns and develop the first codes. 
Responses from four open-ended questions were used to identify and describe teachers' perceptions of the nature of support they needed. There were a total of 211 statements, and each was considered a unit of analysis. In qualitative research data coding schemes can be done inductively or deductively (Fereday \& Muir-Cochrane, 2006). With the inductive method, there are no pre-determined categories. Instead, codes emerge directly from the raw data. On the other hand, deductive methods involved the use of a coding manual that includes data from pre-determined categories.

For this study, inductive coding method was used because the researchers allowed the data to define the codes. Sentence-by-sentence coding assisted the researcher in analyzing the meaning derived from the data (Charmaz, 2006). The researchers searched for commonalities to assign codes. Two researchers read all the statements and coded each one separately. Then the codes were categorized, which was done by sequencing and combining the codes to determine any interrelated patterns emerging. The researchers discussed and agreed upon the specific codes. The researchers grouped codes that were similar into categories. Subsequently, coded combinations were compared to see if a broader classification of the codes was possible. Patterns were identified through comparisons of the basic ideas in each category, and the major themes emerging were selected for discussion.

\subsection{Validity and Trustworthiness}

According to Creswell (2003) validity has different meanings in qualitative research as compared to those in quantitative research. In qualitative research, the researcher is involved in data collection and interpretation of the data; hence there is a need to examine the validity and trustworthiness of the study. To increase the trustworthiness of the findings, the researchers employed various strategies. First, the researchers provided an audit trail, which is a detailed explanation of the data collection and analysis methods. It also shows how decisions were made throughout the study (Lincoln \& Guba, 1985; Merriam, 2002). The researchers also conducted a member checks by contacting the participants to verify the accuracy of the content and the meaning (Creswell, 2003; Lincoln \& Guba, 1985; Merriam, 2002). Also, the rich, thick description was included in the study to enable other researchers to make decisions about transferability (Lincoln \& Guba, 1985; Merriam, 2002).

\subsection{Researcher Positionality}

The two researchers conducted data collection and data analysis. In qualitative research, the researcher's biases and values impact the outcome of any study (Galdas, 2017; Thirsk \& Clark, 2017). Hence, the researchers considered their own biases, limitations, and views throughout data collection, analysis, interpretation, and the reporting phases of the process. To neutralize or bracket their biases, the researchers provided their personal experience germane to this study.

Both researchers worked as teachers of K-12 students who are deaf and hard of hearing who use American Sign Language and English as mediums of instruction. One of the researchers was a teacher for more than 20 years while the other research was a teacher for five years. Their experience as classroom teachers enabled them to come into contact and teach students who are deaf and DSAD. One of the researchers' training during her graduate studies included a focus on teaching DSAD. Currently, both researchers are faculty in a graduate Deaf Education teacher preparation program, in which the majority of their students are currently teachers in the classrooms. Thus, the researchers have an opportunity to interact with classroom teachers during pre-service and in-service training. Understanding the issues and experiences of teachers of students who are deaf and DSAD, and who are, both, beginning teachers and experienced teachers, provides them with an understanding of the different support teachers need when working with DSAD.

Also, both researchers view deaf as ASL/ English bilinguals, and their teacher preparation program adopts an ASL/English bilingual framework. In this framework, the researchers have been immersed in the Deaf community and emphasize the importance of ASL and deaf culture in deaf education. Although they are aware of deaf students who do not use ASL and are not part of the deaf community, their professional affiliation, organizations, conferences, and professional development opportunities, is on ASL/ English bilingual deaf, and hence, may constitute a bias.

\section{Findings}

Six major themes emerged from the study. The number of responses in each category shows the extent of how teachers responded to each category. There were a total of 211 responses that were related to the nature of support provided or needed. Figure 1 shows the various types of supports as reported by the teachers of students who are DSAD. 


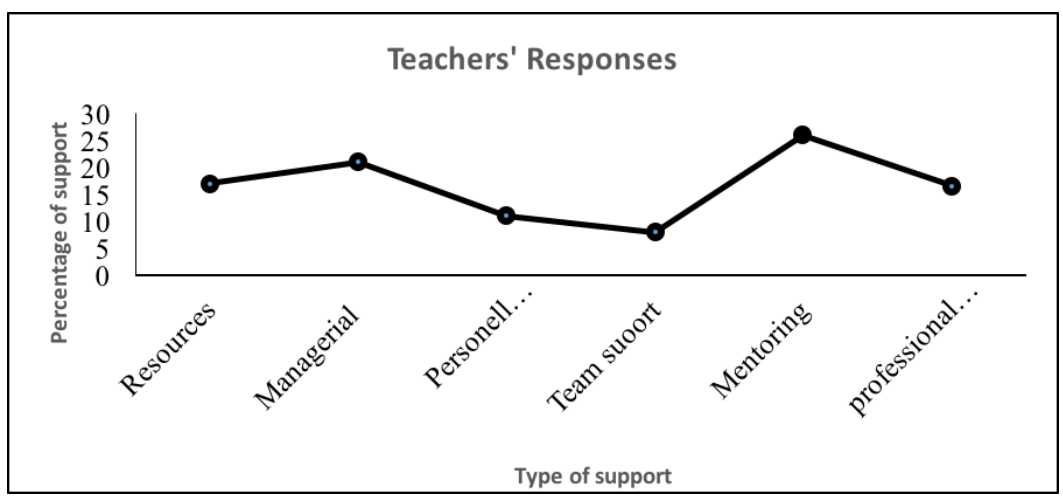

Figure 1. Type of Support Reported by Teachers

\subsection{Resources (36 Responses)}

In most special education classes, teachers have students with various disabilities; hence teachers must modify their lessons to attend to the unique needs of each learner by providing individualized education programs. To do so, teachers rely on the availability and the quality of their resources to attend to the various learning needs in their classrooms. Several responses included general statements of complaints related to the lack of resource support, such as an appropriate curriculum and curriculum materials for implementing the ongoing program. One teacher indicated her lack of support as "to have a special curriculum, standards, and classroom resources ready to help those students with additional disabilities." Related to curriculum, most teachers said they needed support with resource material to implement the curriculum given by the state. One teacher stated, "Finding materials that don't require so many modifications for the different needs of the students (ex: having to add picture communication supports to a passage for English class, as well as making up the independent work also with picture communication supports) can be quite time-consuming." Most teachers reported the issue of time-consumption and curriculum. One teacher said; "For about $99 \%$ of the time, you have to make your materials for instruction. I need support to get materials I can easily modify." Teachers indicated they would save more time if they had materials they could easily adapt.

\subsection{Managerial Support (45 Responses)}

Teachers who teach DSAD in their classrooms have students with more than one disability group and sometimes, different grade levels. These teachers depend upon school administrators and school culture to provide working conditions that enable them to manage their daily challenges at work. Teachers expressed a lack of managerial support, which included adequate time to teach and do non-teaching duties. They also needed clear guidelines regarding job responsibilities. The main issue raised was related to time management and receiving adequate time to do their job efficiently. Several teachers expressed they did not have enough time, even to plan effectively; hence they stayed after school or carried work home daily. Some teachers associated the lack of time as due to paperwork needed. One teacher posited, "The thing I do the least is teaching. Paperwork, computer work, lesson plans to meet the diversity... and so much more take up most of my time."

Lack of guidelines on their responsibilities, both within the school and out of school, made most teachers feel a lack of support. Some teachers were both teachers and job coaches or job placement officers at the same time. Teachers expressed a lack of guidelines on how to do the job placement and lack of support to find job placements for students in the high school and vocational classes. One teacher commented, "I have a hard time trying to find outside jobs that will take my students. A lot of people (non-signers) do not want to take my students in because they cannot sign themselves. My students are not experts at signing either, but they do understand gestures."

Additionally, several responses indicated a lack of support in providing clear guidelines on the teachers' expectation of their responsibilities. The expressions covered all aspects of their role as classroom teachers and their service to students and their parents. One teacher shared, "There are no clear guidelines on our role as teachers of these students. Sometimes there is a conflict of what my role should be as a teacher." Another teacher said, "I am not sure what I am supposed to do and what the parents should be doing. I find myself doing everything for the students, including what I think the parents should do." The lack of clear guidelines not only created role conflicts, but also made teachers feel overwhelmed. As one teacher posited, "My role can be overwhelming because it is not just teaching. I don't know where it should stop."

Finally, students with disabilities transitioning from one grade level to another, and from one school to another, are 
expected to adjust to changes in routines, schedules, teachers, classmates, schedules and buildings. These transitions could be smoother if the school administration offered support to both students and teachers through planning and preparation. Teachers need support information on student-specific information about learning styles, communication systems, medical issues and behavior support that have worked in the past so that precious time is not lost every day figuring how to teach or manage classroom behaviors. During the current study, most teachers expressed the need for support to gain adequate information about each student's needs. Due to the lack of sufficient information in the file about the student's additional disabilities, one teacher said, "I need more meetings set with parents and former teachers so I can get a better understanding of my students and what strategies have been successful in the past."

\subsection{Classroom Support Staff (23 Responses)}

In special education classrooms, they will work as part of a team with many other staff members, including speech therapists, behavioral specialists, occupational therapists, and instructional assistants. The instructional assistants are known by a variety of titles, including para-educator, educational technician, teacher aide, and teacher assistant. The main focus in this theme was the need for support in the classroom by having an appropriate and adequate assistant. Most teachers reported they had support staff in their classroom. A teacher shared how important it was for her school administration to provide her with classroom support staff. "I have an assistant who helps me when needed in managing behavior, so I am better able to focus on teaching and meeting the students' differentiated needs. While I work one-on-one with one student, my assistant works with the other students." Another teacher reported the same support by stating that "We have behavior specialists to assist... some with autism students..."

The data from the current study showed that in most classrooms with DSAD teacher, assistants/provided provide related instructional support for classroom teachers, allowing them more time for lesson planning and teaching. For instance, some teacher assistants assisted in the implementation of a behavioral intervention plan. A few teachers reported they had teacher assistants or aides, but did not feel they were efficient or had minimal understanding of the tasks. Teachers made comments such as "We need professional aides" or "teacher assistants need training" or "aides that have knowledge of students' needs is needed."

\subsection{Team Support (17 Responses)}

Teachers expressed dissatisfaction with the school's interest in their work. Some teachers felt the school administrators, and other teachers considered them as the "other" and did not seem to have much interest in the work they did. One teacher commented that, "I would like more support from administrators. We are known to be in the basement and left behind." Additionally, another teacher posited that, "I feel no one knows what is happening in my classroom unless there is a problem" while another felt that "Most of the time we are on our own."

A few teachers reported their administration considered them as part of the decision-making team and provided them the opportunity to discuss their ideas. One teacher said, "Yes, I have a wonderful department and admin team that is always supportive of whatever I need help with. We bounce ideas and techniques off each other daily." On the contrary, some teachers expressed dissatisfaction with administration understanding them, listening to them, consulting with them before implementing an action, or considering their ideas. One teacher shared, "The administration needs to consider better class placements. A kid is reading on a college level in the same class as a kid who reads on a first-grade level and has severe attention issues, makes it difficult to get progress done." Also, another teacher said, "Understanding what we do. It is frustrating because the school requires that they take the same tests at the end of the year. There is no help when they have to take the state test at the end of the year."

\subsection{Mentoring (55 Responses)}

The responses in this theme explicitly described the practice of having a mentor to provide knowledge and skills to guide beginning and continuing teachers. The need for mentoring was expressed as the absence of qualified, informed personnel to guide the teachers in developing knowledge and skills related to teaching DSAD. Some teachers shared they had no mentoring. One teacher stated "My teaching experience has been challenging and rewarding. I have never had a mentor/teacher/or supervisor take the time to assist me with these issues. I have learned these on my own." Another teacher with similar experiences said that "I started my first day of teaching with no mentor and still today ... 10 years plus experience. A few teachers expressed they were given a mentor. Some of these teachers who received a mentor reported the mentor had no knowledge or experience of teaching DSAD. One teacher said, "I was assigned a mentor, but I think it is important to have a mentor in this area... not just deaf education." Another teacher said, "I don't get a lot of support from the supervisor of deaf education here. I ask other teachers that are teaching hearing students with disabilities. I can get better ideas from them." Others got a mentor, 
but there were no clear guidelines about the mentor. One teacher stated, "I do have an unofficial mentor... mentors provide help on different issues that arise."

Further, teachers reported that they were rarely provided any meaningful feedback or ideas on how to teach DSAD. One teacher commented, "I don't know whether I am doing right or wrong. I have to plan myself to observe other classrooms to compare and improve my teaching style for the best." Another teacher said, "Not many people in the district know anything about DSAD. It is the same here in school." Also, one teacher observed that "Most of the time I can get materials if I ask them. I have gotten lots of materials that may help in my class. However, I have to tell them what I need. They don't tell me what to use with these students. They don't tell me how to use materials with these students." Consequently, for better mentoring support, teachers felt that the school administrators needed to be more explicit in assigning mentors and to provide guidelines indicating the role of the mentor and mentee.

While most teachers responded to having challenges with a mentor, there were a few teachers who expressed great administrative support in supporting mentoring. One teacher reported, "We have a good mentoring system. Our school district has a mentor program. Another teacher said, "I was assigned mentors who are willing to set up a meeting and discuss any questions/concerns as well as assist with developing goals and objectives for the following year." Two teachers reported they had no mentors, but the school administration hired a special needs teacher that would assist with issues and suggested ideas for teachers to implement.

\subsection{Professional Development: (35 Responses)}

Professional development comprised of access to adequate information about the students and attendance to in-services, seminar/workshop to provide teachers' knowledge, and skills in teaching deaf with additional disabilities. The data showed that, although teachers had opportunities for in-service and professional development workshops, these meetings did not target DSAD. As one teacher said, "We have in-service workshops/seminars but not related to our deaf students with LD, ADHD, autism, and other issues." Another teacher sharing said, "Our school district has no workshops on deaf plus...There is no special workshop here." Further, teachers identified the type of practical support they needed. One teacher said, "We need intensive workshops on teaching DSAD." While another said, "We need workshops on behavior management of DSAD."

\section{Discussion}

The current study examined teachers of DSAD perceptions of the nature of support they needed or received from their schools. The current findings from this study concurred with previous research that showed special education teachers are frustrated by the lack of adequate school supplies, materials, and resources (Billingsley, 2003; Billingsley, Carlson, \& Klein, 2004; Gerhke \& McCoy, 2007; Kaufhold, Alverez, \& Arnold 2006). According to Kaufhold, Alverez, \& Arnold (2006) study, approximately $90 \%$ of the 228 teachers of students with special needs, who are three years to twenty-two years old, who participated in the study, reported frustration due to lack of sufficient materials and resources to teach effectively. In Kaufohold et al., (2006) study, among the teachers who participated, none asserted that they had adequate supplies. Gerhke and McCoy (2007) study, which involved an interview with five special education teachers, described the need to acquire instructional materials. She also mentioned that she had to bring her materials to use in the classroom. Additionally, similar to the findings in the current study, due to lack of sufficient supplies, teacher are often forced to use "out-of-pocket" money to purchase classroom supplies, materials and equipment (Abel \& Sewell, 1999; Gerhke and McCoy, 2007; Kaufhold, Alverez, $\&$ Arnold 2006). These findings indicate a need to revisit the federal funding through the IDEA, which is expected to provide financial support to educate students with special needs including DSAD.

In the current study, one area of concern and lack of support expressed from teachers of DSAD was the support to get information about the various disabilities and the learning needs of their students other than an IEP. Previous research on transitions and students with disabilities showed that the receiving teacher must be involved in the transitions, by attending annual case conferences or the transition planning meetings so that information available about strategies that have worked in the past, needed modifications and adaptations, positive behavior support strategies, and methods of communication can be shared (Akos \& Galassi, 2004; Frasier, 2007; Pratt, 2000). An example of strong support for information is reported by Frasier (2007) who examined how the Westminster School facilitates the support for the middle school and high school teachers of students with disabilities. In Westminster school, the administration used the existing framework of the Individualized Education Plan (IEP) meeting and intentionally established partnerships with the middle school counterparts and personalized communications among professionals, as well as parents before and after the transition. 
In the United States the Individuals with Disabilities Education Act (IDEA) requires beginning at age 16 (or younger, if determined appropriate by the IEP team), the IEP must contain a statement of needed transition services for a student with disabilities. With such requirements, the role of a special educator has expanded to include the provision of transition and specialized services needed. Most special education teachers have content knowledge of special education but lack specific knowledge of transition skills and community services (Conderman \& Katsiyannis, 2002; Thoma, Held, \& Saddler, 2002; Zhang, Ivester, Chen, \& Katsiyannis, 2005). The findings from these previous studies concur with the current study findings in which teachers expressed lack of support for implementing transition activities, such as job placement and job coaching for the high school students who are DSAD. Similar to previous findings, most teachers of DSAD have content knowledge about Deaf education; hence the school administration needs to support teachers of DSAD who teach students who are 16 years and above by providing them skills and knowledge on meeting their students IEP transition goals.

Classroom assistants are also an essential part of the staffing structure of many individual education classrooms. Although the special education teacher is expected to plan instruction, which is then carried out by the teacher assistants studies, show that their work has become more instructional than supportive and hence, they need training to do their roles (Giangreco \& Broer, 2005; Werts, Zigmond, \& Leeper, 2001). Also, studies have shown assistant teachers show how teachers are busy and rarely have time to provide the training and supervision the teacher assistant need. Giangreco and Broer (2005) reported that special education teachers devote less than $2 \%$ of their time to individual supervision of teacher assistants. Previous research shows there is no clear guidance on who should provide training, supervision, and evaluation of teacher assistants to ensure teachers are receiving the classroom support they need (Brock \& Carter, 2015; Locke, Kratz, Reisinger, \& Mandell, 2014). Hence, it is not surprising that most teachers of DSAD may be having classroom support staff that are not trained or whose roles and responsibilities are not explicitly described or explained to the classroom, making the teacher feel they have personnel who are not helping them meet their expectation of them.

The teaching experience of the participants in this study varied. Eight teachers had one to five years of teaching experience, eleven teachers had six to ten years, and twenty one teachers had more than ten years of experience. Although the difference in teaching experience, mentoring was identified as one type of administrative support that the teachers needed. The need for mentoring echoes in previous studies which identified mentoring as critical support for teachers (Graves, 2010; Leimann, Murdock, \& Waller, 2008; Whitaker, 2000). The effectiveness of the mentor depended on both their knowledge and competency (Darling-Hammond, 2003; Dempsey, Arthur-Kelly, \& Carty, 2009; Graves, 2010). According to Dempsey, Arthur-Kelly, \& Carty, 2009 they must have someone who can address specific problems and provide them with sound advice. In the current study, several teachers reported having been assigned mentors that had no knowledge or experience to teach DSAD; hence they were not able to offer them the support they needed.

The problem of identifying and matching teachers may result from a lack of available mentors on-site. With the advent of technology, an emerging trend in mentoring is the value of electronic mentoring, or e-mentoring (Smith \& Israel, 2010; White \& Mason, 2006). In White and Mason (2006) study, the location of the mentor was found not to affect the mentoring experience. Based on previous findings, the lack of available mentors on-site for teachers of DSAD can be resolved by the principal organizing e-mentors from other schools or universities who have access to video web conferencing, video modeling, emails among other technologies to support the teachers.

Also, the current study uncovered the need for team player support as necessary for teachers of DSAD. The need to provide teachers with a sense of team players, reported in the current study, echoed previous studies that showed how school administrators support teachers by listening and including teachers' voice in decision making (Hansson \& Gamage, 2008; Many (2008). According to Many (2008), the need to provide team player support can be achieved by administrators scheduling teacher collaboration during the school day. This sends a clear message of the importance of collaboration in which the teacher feels they are involved on issues regarding their students' learning process and outcomes.

Finally, the current study findings reiterated the importance of professional development as a key component in supporting teachers (Cheetham \& Chivers, 2001; Eraut, 2004). The primary concerns in the professional development for teachers of DSAD were to be offered with professional development that addressed their specific needs of teaching DSAD. The teachers' responses in the current study tended to focus on formal professional development, which means a conference, seminar, or workshop (Mizell, 2010). Other definitions of professional development include informal contexts such as discussions among work colleagues, observations of a colleague's work, or other learning from a peer through social media and social network sites (van Bommell \& Liljekvist, 2016; 
Mizell, 2010). Most schools may not be able to offer a formal traditional professional development, but National Staff Development Council (NSDC) (2001) suggests informal professional development can be made available by school districts by dedicating at least $25 \%$ of an educator's work time to be devoted to learning and collaboration with colleagues. Following the recommendation of NSDC, $25 \%$ of the educators' time can also be used to provide teachers to participate in e-mentoring, which allows teachers to be matched with mentors who are off site (Dempsey et al., 2009; Israel, Carnahan, Snyder, \& Williamson, 2013).

\section{Limitations of the Study}

The sample size for this study was small because it included only 40 teachers from only five schools. Another limitation of the study was that the participating teachers were teaching in classrooms that all the students were deaf and users of ASL. Research shows that today many deaf students are mainstreamed in public schools (Antia, Stinson \& Gaustad, 2002; Reed, Antia, \& Kreimeyer, 2008), it is possible that teachers in mainstream classrooms may have DSAD in their classes and their experiences are not included in this research.

\section{Implications and Recommendations for Future Studies}

The study's findings have implications for schools with teachers working with students with disabilities. Schools with deaf students need to recognize the difference between teaching DSAD and those without disabilities. Besides recognizing the task for teachers of DSAD, school administration needs to be intentional in providing support to teachers of DSAD. Similarly, mainstream programs with deaf students must be intentional to understand and support deaf students that may have additional disabilities. Teacher retention depends on the nature of support teachers receive (Carroll \& Fulton, 2004; National Commission on Teaching and America's Future, 2012). To reduce teacher burn-out and improve attrition rates, additional studies are needed to improve the support for teachers in the classroom. This study's findings have implications for higher education programs that focus on training school leaders. Training programs on educational leadership need to include foundational knowledge on administration in special education programs. The knowledge is essential to facilitate school supervisors to become intentional about how to support their teachers, including those teaching students with disabilities.

Finally, future studies need a larger sample that will draw teachers from various educational settings to explore the nature of their perceptions of support needed. Also, future studies should examine the impact of teachers' support on students learning and performance. Finally, there is a need to understand administrators' perspectives and support teachers of students with special needs including DSAD.

\section{References}

Abel, M. H., \& Sewell, J. (1999). Stress and Burnout in Rural and Urban Secondary School Teachers. The Journal of Educational Research, 92(5), 287. https://doi.org/10.1080/00220679909597608

Albrecht, S. F., Johns, B., Mounsteven, J., \& Olorunda, O. (2009). Working conditions as risk or resiliency factors for teachers of students with emotional and behavioral disabilities. Psychology in the Schools, 46, 1006-1022. https://doi.org/10.1002/pits.20440

Akos, P., \& Galassi, J. P. (2004). Middle and high school transitions as viewed by students, parents, and teachers. Professional School Counseling, 7(4), 212-221.

Alderman, M. K. (2004). Motivation for achievement: possibilities for teaching and learning. Mahwah NJ: Lawrence Erlbaum.

Antia, S., Stinson, M., \& Gaustad, M. (2002). Developing Membership in the Education of Deaf and Hard-of-Hearing Students in Inclusive Settings. Journal of Deaf Studies and Deaf Education, 7(3), 214-229. https://doi.org/10.1093/deafed/7.3.214

Apling, R. N., \& Jones, N. L. (2005). Individuals with Disabilities Education Act (IDEA): Analysis of Changes Made by P.L. 108-446. Retrieved from https://cec.sped.org/ /media/Files/Policy/IDEA/CRS\%20IDEA\%20Report.pdf

Barchard, K. A., \& Williams, J. (2008). Practical advice for conducting ethical online experiments and questionnaires for United States psychologists. Behavior Research Methods, 40, 1111-1128. https://doi.org/10.3758/BRM.40.1111 
Billingsley, B. S. (2004). Promoting teacher quality and retention in special education. Journal of Learning Disabilities, 37, 370-376. https://doi.org/10.1177/00222194040370050101

Billingsley, B. S. (2003). Special education teacher retention and attrition: A critical analysis of the literature (COPSSE Document No. RS-2E). Gainesville, FL: University of Florida, Center on Personnel Studies in Special Education.

Billingsley, B., Carlson, E., \& Klein, S. (2004). The working conditions and induction support of early career special educators. Exceptional Children, 70, 333-347. https://doi.org/10.1177/002246699302700202

Billingsley, B. S., \& Cross, L. H. (1992). Predictors of commitment, job satisfaction, and intent to stay in teaching: A comparison of general and special educators. The Journal of Special Education, 25(4), 453-471. https://doi.org/10.1177/002246699202500404

Bogdan, R. C., \& Biklen, S. K. (2003). Qualitative research for education: An introduction to theories and methods (4th ed.). New York, NY: Pearson Education Group.

Brock, M. E., \& Carter, E. W. (2015). Effects of a professional development package to prepare special education paraprofessionals to implement evidence-based practice. The Journal of Special Education. 4, 39-51. https://doi.org/10.1177/0022466913501882

Bruce, S., DiNatale, P., \& Ford, J. (2008). Meeting the needs of deaf and hard of hearing students with additional disabilities through professional teacher development. American Annals of The Deaf, 153(4), 368-375. Https://doi.org/10.1353/aad.0.0058

Buchanan, E. A., \& Hvidzak, E. E. (2009). Online survey tools: Ethical and methodological concerns of Human Research Ethics Committees. Journal of Empirical Research on Human Research Ethics, 4, 37-48. https://doi.org/10.1525/jer.2009.4.2.37

Cancio, E., Albrecht, F. S., \& Johns, H. B. (2013). Defining administrative support and its relationship to the attrition of teachers of students with emotional and behavioral disorders. Journal of education and Treatments of Children, 36(4), 71-94. https://doi.org/10.1353/etc.2013.0035

Carroll, T., \& Fulton, K. (2004). The true cost of teacher turnover. Threshold, 16-17.

Charmaz, K. (2006). Constructing grounded theory. A practical guide through qualitative analysis. London: Sage.

Cheetham, G., \& Chivers, G. (2001). How professionals learn in practice: An investigation of informal learning amongst people working in professions. Journal of European Industrial Training, 25, 248-292. https://doi.org/10.1108/0309059011039587

Comer, S. K. (2009). The ethics of conducting educational research on your own students. Journal of Nursing Law, 13(4), 100-105. https://doi.org/10.1891/1073-7472.13.4.100

Conderman, G., \& Katsiyannis, A. (2002). Instruction issues and practices in secondary special education. Remedial and Special Education, 23, 169-179. https://doi.org/10.1177/07419325020230030501

Creswell, J. W. (2013). Research design: Qualitative, quantitative, and mixed methods approaches. Thousand Oaks, CA: Sage publications.

Creswell, J. W. (2005). Educational research: Planning, conducting, and evaluating quantitative and qualitative research (2nd ed.). Upper Saddle River, NJ: Pearson.

Cross, L. H., \& Billingsley, B. (1994). Testing a model of special educators' intent to stay in teaching. Exceptional Children, 60(5), 411-421. https://doi.org/10.1177/001440299406000504

Darling-Hammond, L. (2003). Keeping good teachers. Educational Leadership, 60(8), 6.

Dempsey, I., Arthur -Kelly, M., \& Carty, B. (2009). Mentoring early career special education teachers. Australian Journal of Education, 53(3), 294-305. https://doi.org/10.1177/000494410905300307

Denzin, N. K., \& Lincoln, Y. S. (2003). The landscape of qualitative research: Theories and issues (2nd ed.). Thousand Oaks, CA: Sage.

Dodd, E. E., \& Scheetz, N. A. (2003). Preparing today's teachers of the deaf and hard of hearing to work with tomorrow's students: A statewide needs assessment. American Annals of the Deaf, 148, 25-30. https://doi.org/10.1353/ aad.2003.0002

Dornyei, Z. (2007). Research methods in applied linguistics. New York: Oxford University Press. 
Eraut, M. (2004). Informal learning in the workplace. Studies in Continuing Education, 26, 247-273. https://doi.org/10.1080/158037042000225245

Fereday, H., \& Muir-Cochrane, E. (2006). Demonstrating rigor using thematic analysis: A hybrid approach of inductive and deductive coding and theme development. International Journal of Qualitative Methods, 5(1), 80-92. https://doi.org/10.1177/160940690600500107

Ferguson, L. M., Yonge O., \& Myrick, F. (2004). Students' involvement in faculty research: Ethical and methodological issues. International Journal of Qualitative Methods, 3(4), Article 5.

Frasier, J. R. (2007). Transitioning students with disabilities from middle to high school. Teaching Exceptional Children Plus, 4(2), 1-10.

Galdas, P. (2017). Revisiting Bias in Qualitative Research: Reflections on Its Relationship with Funding and Impact. International Journal of Qualitative Methods, 16(1). https://doi.org/10.1177/1609406917748992

Gersten, R., Keating, T., Yovanoff, P., \& Harniss, M. K. (2001). Working in special education: Factors that enhance special educator's intent to stay. Exceptional Children, 67, 549-567. https://doi.org/10.1177/001440290106700408

Gerhke, R. S., \& McCoy, K. (2007). Considering the context: Differences between the environments of beginning special educators who stay and those who leave. Rural Special Education Quarterly, 26(3), 32-40. https://doi.org/10.1177/875687050702600305

Graves, S. (2010). Mentoring pre-service teachers: A case study. Australasian Journal of Early Childhood, 35(4), 14-20. https://doi.org/10.1177/183693911003500403

Giangreco, M. F., \& Broer, S. M. (2005). Questionable utilization of paraprofessionals in inclusive schools: Are we addressing symptoms or causes? Focus on Autism and Other Developmental Disabilities, 20, 10-26. https://doi.org/10.1177/10883576050200010201

Griffin, C. C., Kilgore, K. L., Winn, J. A., Otis-Wilborn, A., Hou, W., \& Garvan, C. W. (2009). First-year special educators: The influence of school and classroom context factors on their accomplishments and problems. Teacher Education and Special Education, 32(1), 45-63. https://doi.org/10.1177/0888406408330870

Guardino, C., \& Cannon, J. E. (2015). Theory, Research, and Practice for Students Who Are Deaf and Hard of Hearing with Disabilities: Addressing the Challenges from Birth to Postsecondary Education. American Annals of the Deaf, 160(4), 347-355. https://doi.org/10.1353/aad.2015.0033

Hansson, P., \& Gamage, D. (2008). A study of professional development of Swedish school leaders and their views on how it needs to be navigated. World Studies in Education, 9(1), 55-72. https://doi.org/10.7459/wse/09.1.04

Ingersoll, R. M. (2001). Teacher Turnover and Teacher Shortages: An Organizational Analysis. American Educational Research, 38(3), 499-534. https://doi.org/10.3102/00028312038003499

Israel, M., Carnahan, C. R., Snyder, K. K., \& Williamson, P. (2013). Supporting new teachers of students with significant disabilities through virtual coaching: A proposed model. Remedial and Special Education, 34(4), 195-204. https://doi.org/10.1177/0741932512450517

Jones, T. W., \& Ewing, K. M. (2002). An analysis of teacher preparation in deaf education: Programs approved by the Council on Education of the Deaf. American Annals of the Deaf, 147, 71-78. https://doi.org/10.1353/aad.2012.0246

Katsafanas, J. D. (2006). The Roles and Responsibilities of Special Education Teachers. Unpublished doctoral dissertation, University of Pittsburgh.

Kaufhold, J., Alverez, V., \& Arnold, M. (2006). Lack of school supplies, materials and resources as an elementary cause of frustration and burnout in South Texas special education teachers. Journal of Instructional Psychology, 33(3), 159-161.

Leimann, K., Murdock, G., \& Waller, W. (2008). The staying power of mentoring. Delta Kappan Gamma Bulletin, 74(3), 28-31.

Lincoln, Y. S., \& Guba, E. G. (1985). Naturalistic inquiry. Beverly Hills, CA: Sage Publications.

Locke, J., Kratz, H., Reisinger, E., \& Mandell, D. (2014). Implementation of evidence-based practices for children with autism spectrum disorders in public schools. In Beidas R. \& Kendall P. (Eds.), Child and adolescent therapy: Dissemination and implementation of empirically supported treatments. Oxford University Press; New York, NY. 
pp. 261-276.

Luckner, J. L., \& Carter, K. (2001). Essential competencies for teaching students with hearing loss and additional disabilities. American Annals of the Deaf, 146, 7-15. https://doi.org/10.1353/ aad.2012.0065

Mahon, P. Y. (2013). Internet research and ethics: Transformative issues in nursing education research. Journal of Professional Nursing, 30, 124-129. https://doi.org/10.1016/j.profnurs.2013.06.007

Many, T. W. (2008). Teacher talk: how collaboration gets to the heart of great schools. In Erkens, C., Jakicic, C. (Eds.), The Collaborative Teacher (pp. 57-75). Bloomington, IN: Solution Tree.

Martin, J. J. (2008). Study of factors that contribute to the exit of special education teachers from the special education classroom in region 1 of Kansas. Unpublished doctoral dissertation, Baker University.

McGrew, K. M., Johnson, D., Cosio, A., \& Evans, J. J. (2004). Increasing the chance of no child being left behind: Beyond cognitive and achievement abilities. Minneapolis, MN: Institute on Community Integration, University of Minnesota.

Merriam, S. B. (2002). Qualitative research in practice: Examples for discussion and analysis. San Francisco, CA: Jossey-Bass.

Mizell, H. (2010). Why professional development matters. Learning Forward: Oxford, OH.

Musyoka, M. M., Gentry, M. A., \& Bartlett, J. J. (2016). Voices from the Classroom: Experiences of Teachers of Deaf Students with Additional Disabilities. Journal of Education and Training Studies, 4(2), 85-96. https://doi.org/10.11114/jets.v4i2.1113

Musyoka, M. M., Gentry, A.M., \& Meek, D. (2017). Perceptions of teachers' preparedness to teach deaf and hard of hearing students with additional disabilities: A Qualitative case study. Journal of Developmental and Physical Disabilities. https://doi.org/10.1007/s10882-017-9555-z

National Commission on Teaching and America's Future. (2012). What matters most: teaching for America's future. Retrieved from nctaf.org/wp-content/uploads/ 2012/WhatMattersMost.pdf

National Staff Development Council. (2001). NSDC's standards for staff development. NSDC, Oxford, OH.

Otto, S., \& Arnold, M. (2005). A study of experienced special education teachers' perceptions of administrative support. College Student Journal, 39, 253-259.

Patton, M. Q. (2002). Qualitative Research \& Evaluation Methods (3rd ed.). Newbury Park, CA: Sage

Pratt, C. (2000). Planning for successful transitions across grade levels. Bloomington, IN: Indiana Resource Center for Autism.

Prather-Jones, B. (2011). How school administrators influence the retention of teachers of students with emotional and behavioral disorders. The Clearing House: A Journal of Educational Strategies, Issues and Ideas, 84(1), 1-8. https://doi.org/10.1080/00098655.2010.489387

Reed, S., Antia, D. S., \& Kreimeyer, H. K. (2008). Academic Status of Deaf and Hard-of-Hearing Students in Public Schools: Student, Home, and Service Facilitators and Detractors. The Journal of Deaf Studies and Deaf Education, 13(4), 485-502. https://doi.org/10.1093/deafed/enn006

Richards, J. (2004). What New Teachers Value Most in Principals? Principal, 83(3), 42-44.

Richards, J. (2007). How Effective Principals Encourage Their Teachers Principal. Principals, Jan/Feb, 48-50.

Ridley, R. T. (2009). Assuring ethical treatment of students as research participants. Journal of Nursing Education, 48, 537-541. https://doi.org/10.3928/01484834-20090610-08

Skaalvik, E. M., \& Skaalvik, S. (2007). Dimensions of teacher self-efficacy and relations with strain factors, perceived collective teacher efficacy, and teacher burnout. Journal of Educational Psychology, 99, 611-625. https://doi.org/10.1037/0022-0663.99.3.611

Smith, M. S., \& Ingersoll, M. R. (2004). What Are the Effects of Induction and Mentoring on Beginning Teacher Turnover? American Educational Research Journal, $41(3), \quad 681-714$ https://doi.org/10.3102/00028312041003681.

Smith, S. J., \& Israel, M. (2010). E-mentoring: Enhancing special education teacher induction. Journal of Special Education Leadership, 23, 30-40. 
Stronge, J. H. (2002). Qualities of effective teachers. Alexandria, VA: Association forSupervision and Curriculum Development.

Thirsk, L. M., \& Clark, A. M. (2017). Using qualitative research for complex interventions: The contributions of hermeneutics. International Journal of Qualitative Methods, 16(1). https://doi.org/10.1177/1609406917721068.

Thoma, C. A., Held, M. F., \& Saddler, S. (2002). Transition assessment practices in Nevada and Arizona: Are they tied to best practices? Focus on Autism and Other Developmental Disabilities, 17, 242-250. https://doi.org/10.1177/10883576020170040701

Tsiplakides, I., \& Keramida, A. (2010). The Relationship between Teacher Expectations and Student Achievement in the Teaching of English as a Foreign Language. English Language Teaching, 3(2), 22-26.

Tuck, B. M. (2010). Preserving facts, form and function when a deaf witness with minimal language skills testified in court. University of Pennsylvania Law Review, 158(3), 905-956. https://doi.org/10.2307/20698348

Van Bommel, J., \& Liljekvist, Y. (2016, October). Teachers' informal professional development on social media and social network sites: when and what do they discuss? Paper presented at the ERME Topic Conference on Mathematics teaching, resources and teacher professional development, Berlin, Germany.

Wasburn-Moses, L. (2005). Roles and Responsibilities of Secondary Special Education Teachers in an Age of Reform. Remedial \& Special Education, 26(3), 151-158. https://doi.org/10.1177/07419325050260030301

Werts, M., Zigmond, N., \& Leeper, D. (2001). Paraprofessional Proximity and Academic Engagement: Students with Disabilities in Primary Aged Classrooms. Education and Training in Mental Retardation and Developmental Disabilities, 36(4), 424-440

Whitaker, S. D. (2000). Mentoring beginning special education teachers and the relationship to attrition. Exceptional Children, 66, 546-566. https://doi.org/10.1177/001440290006600407

White, M., \& Mason, C. Y. (2006). Components of a successful mentoring program for beginning special education teachers: Perspectives from new teachers and mentors. Teacher Education and Special Education: The Journal of the Teacher Education Division of the Council for Exceptional Children, 29, 191-201. https://doi.org/10.1177/088840640602900305

Yin, R. K. (2009). Case study research design methods (4th ed.). Los Angeles, CA: Sage.

York-Barr, J., Sommerness, J., Duke, K., \& Ghere, G. (2005). Special educators in inclusive education programs: reframing their work as teacher leadership. International Journal of Inclusive Education, 9, 193-215. https://doi.org/org/10.1080/1360311042000339374

Zabel, R. H., \& Zabel, M. K. (2002). Burnout among special education teachers and perceptions of support. Journal of Special Education Leadership, 15, 67-73.

Zhang, D., Ivester, J. G., Chen, L. J., \& Katsiyannis, A. (2005). Perspectives on transition practices. Career Development for Exceptional Individuals, 28, 15-25. https://doi.org/10.1177/08857288050280010401

Zigmond, N. (1995). An exploration of the meaning and practice of special education in the context of full inclusion of students with learning disabilities. Journal of Special Education, 29, 109-116. https://doi.org/10.1177/002246699502900201 